\title{
Effect of short term exercise on abdominal obesity and blood pressure
}

\author{
Vandana B Dudhamal ${ }^{1}$, Sayeda Afroj ${ }^{2}$ \\ ${ }^{1}$ Dr. Vandana B Dudhamal, Professor and HOD, Department of Physiology, SMCRC, Guna, M.P. ${ }^{2}$ Dr. Sayeda \\ Afroj, Professor and HOD, Department of Physiology, Govt Medical College, Aurangabad, Maharashtra, India. \\ Corresponding Author: Dr. Vandana Dudhamal, Email: dudhamalv@gmail.com.
}

\begin{abstract}
Introduction: obesity is associated with a variety of chronic diseases, including but not limited to coronary artery disease, hypertension, diabetes, and certain forms of cancer. The present study was designed to examine the effects of short-term exercise on markers of obesity. Material and methods: This was a randomized trial in 52 overweight and obese [body mass index (in $\mathrm{kg} / \mathrm{m} 2$ ): $25-40$; waist circumference $>88 \mathrm{~cm}$ ], women assigned to 16 week interventions of short term Exercise ( $3 \mathrm{~d} / \mathrm{wk}$ ) involved treadmill walking at an intensity of $45-50 \%$ (moderate-intensity) or 70-75\% (vigorous-intensity) of heart rate reserve. The primary outcome was abdominal visceral fat volume determined by the measurement of waist and hip circumferences ratio. Results: Average height of the females under study is $159.96 \mathrm{~cm}$ and average weight of females before exercise is $68.92 \mathrm{~kg}$, it shows that the females in our study are overweight. After exercise training program, weight, arm circumference, chest circumference, WHR and BMI decreased significantly $(Z=4.27,7.30,4.99,8.51$ and 3.27 respectively ). Similarly systolic blood pressure and diastolic blood pressure ( $Z=5.74$ and 1.75 respectively) was decreased significantly after exercise training. Conclusion: Short term exercise intervention can induce favourable changes in the body composition, but the magnitude of these changes is of limited biological significance.
\end{abstract}

Keywords: Exercise, Body mass index, Waist hip ratio

\section{Introduction}

Obesity is defined as the presence of excess adipose tissue. A person whose body weight is in excess of standard weight (calculated from BMI \& Hip Waist Ratio) is termed as overweight [1].

The obesity epidemic in children and adolescents is well recognized and poses a major threat to the health and longevity of American children. Just as obesity in adults is associated with chronic diseases such as cardiovascular disease, type 2 diabetes, metabolic syndrome, and certain forms of cancer $[2,3]$ some have suggested that the women of today may be the first generation not to outlive their parents due to the premature development of these obesity-related diseases [4]. In the context of epidemiological studies, body mass index (BMI, weight/height2) in adults is currently considered as a diagnostic test (separator variable) which is able

Manuscript received: $7^{\text {th }}$ July 2017

Reviewed: $17^{\text {th }}$ July 2017

Author Corrected: $24^{\text {th }}$ July 2017

Accepted for Publication: $29^{\text {th }}$ July 2017 to identify overweight $(25 \mathrm{~kg} / \mathrm{m} 2)$ and obese (30 $\mathrm{kg} / \mathrm{m} 2$ ) individuals and may predispose to increased CMD risk, morbidity and mortality [5,6] demonstrating interruption of sedentary time with brief moderate-intensity walking resulted in an improvement of short-term metabolic function in non-overweight people without increasing subsequent energy intake [7].

Despite the difficulty in directly comparing studies because of the variety of environmental factors and defined end-points, systematic reviews consistently highlight that better and safer access to physical activity resources are directly related to increased leisure time physical activity in women, which subsequently decreases the risk of developing obesity [8-12].

So this study was undertaken to see the effect of short term exercise in abdominal obesity and blood pressure in women. 


\section{Material and Methods}

The present randomised control study was carried out in the Department of physiology of tertiary care teaching hospital of the central India. Fifty two overweight and obese women were studied for short term exercise trial and its effect on reduction of obesity parameters.

Inclusion criteria: Women of age 25 to 45 years attending health center and living sedentary life style were included. To be eligible, participants were required to report no participation in regular structured exercise and that they did not do $>30 \mathrm{~min}$ of moderate-intensity exercise, accumulated in 10 min bouts, on most days of the week.

Exclusion criteria: women were taking prior medications, Individuals who smoked, suffered from a condition known to interact with the study measures or took regular medication that may have interfered with the results were excluded from the study.

Methods: women aged 25 - 45 years who visited the outpatient clinics in a regional teaching hospital for evaluation of their obesity were screened. The risk factors were as follows: hypertension (defined as resting sitting blood pressure $>140 / 90 \mathrm{mmHg}$, or $>130 / 80 \mathrm{mmHg}$ for diabetic participants), dyslipidemia (fasting blood lipid levels within 3 months prior to entering the study showed that total cholesterol > $200 \mathrm{mg} / \mathrm{dl}$, LDL cholesterol > 129 $\mathrm{mg} / \mathrm{dl}$, HDL cholesterol $<50 \mathrm{mg} / \mathrm{dl}$, or triglyceride $>150 \mathrm{mg} / \mathrm{dl}$ ), type 2 diabetes (fasting blood glucose $>126 \mathrm{mg} / \mathrm{dl}$ ) or obesity (body mass index $($ BMI $)>24 \mathrm{~kg} / \mathrm{m} 2$ or waist to hip ratio $>0.82$ ). Informed consent was obtained from each participant. Thereafter, the participants were assigned into exercise according to the availability to attend the treadmill exercise. They underwent treadmill training, 30 minutes each time and three times a week, for continuous 16 weeks. Each participant achieved $60-80 \%$ of maximum heart rate during the exercise. At the end of the 16 weeks, all participants were examined to obtain the data of fasting blood lipids and sugar, resting blood pressure, and body composition, including waist tohip ratio and BMI. BMI was defined as weight $(\mathrm{kg})$ divided by height square $(\mathrm{m} 2)$. In brief, waist was measured at the narrowest part of the torso (above the umbilicus and below the xiphoid process); hip, at the maximal circumference of the hip or buttock region, whichever was larger (above the gluteal fold). Blood pressure was measured in a sitting position by a sphygmomanometer after resting for 5 minutes the average of two sequential measurements was entered into our records.

Exercise: Exercise testing and exercise training was conducted a TAKASUMA 830BL treadmill equipped with HP type 78351-T electrocardiogram to monitor heartbeat. Modified Bruce protocol was adopted for exercise testing. Target heart rate (THR) was calculated using Karvonen's method: Resting HR + 60\% 80\% (maximal HR-resting $\mathrm{HR})$. Exercise training included warm-up with 1.7 mph, $0 \%$ grade for 5 minutes, then adjusting the level according to individual's target HR for 30 minutes on treadmill and cooling down 5 minutes. Participants' ST variation on electrocardiogram, blood pressure, and status quo before every switch on the grade of treadmill were carefully monitored.

Statistical analysis- All analyses were performed with the use of SAS software, version 9.1 and an $\alpha$ of 0.05 was used as the type I error rate. All analyses were conducted under the intent-to-treat model with intervention assignment based on the assigned intervention at time of randomization.

Baseline characteristics are reported as mean $( \pm \mathrm{SD})$ and analysed by "Z" test. Simple bivariate correlation and regression analyses were performed to examine relations between mean changes in the primary and secondary outcomes with baseline values of these outcomes

\section{Results}

Average height of the females under study is $159.96 \mathrm{~cm}$ and average weight of females before exercise is 68.92 $\mathrm{kg}$, it shows that the females in our study are overweight. After exercise training program, weight, arm circumference, chest circumference, WHR and BMI decreased significantly $(Z=4.27,7.30,4.99,8.51$ and 3.27 respectively ). Similarly systolic blood pressure and diastolic blood pressure ( $Z=5.74$ and 1.75 respectively) was decreased significantly after exercise training. 
Table: 1: Comparison of variables before and after 16 weeks of exercise training program( Mean \pm S.D)

\begin{tabular}{|c|c|c|c|}
\hline Variable & Before exercise & After exercise & Significance “ $Z$ ' \\
\hline Weight $(\mathrm{kg})$ & $68.92 \pm 9.74$ & $60.75 \pm 9.79$ & Significant \\
\hline BMI $(\mathrm{kg} / \mathrm{m} 2)$ & $26.73 \pm 3.99$ & $24.17 \pm 3.99$ & Highly significant \\
\hline WHR & $0.93 \pm 0.051$ & $0.84 \pm 0.056$ & Highly significant \\
\hline Upper arm circumference $(\mathrm{cm})$ & $13.71 \pm 1.36$ & $12.11 \pm 1.16$ & Highly significant \\
\hline Chest circumference $(\mathrm{cm})$ & $38.01 \pm 2.66$ & $35.63 \pm 2.84$ & Highly significant \\
\hline Systolic BP $(\mathrm{mm} \mathrm{Hg})$ & $118.76 \pm 4.62$ & $113.53 \pm 4.67$ & Highly significant \\
\hline Diastolic BP $(\mathrm{mm} \mathrm{Hg})$ & $77.11 \pm 3.88$ & $75.84 \pm 3.66$ & Highly significant \\
\hline
\end{tabular}

$* Z>2$ SE, Significant; $Z>3$ SE, highly significant.

\section{Discussion}

Obesity is closely related to socioeconomic environment .In some societies lean and thin individuals are socially branded as undernourished and are encouraged to put on weight. Economic prosperity is usually associated with increased prevalence of obesity due to increased availability and consumption of tasty foods rich in sugar, fat and calories and decreased need for physical activity. Mainly obesity is problem of higher class and middle class women living sedentary life style.

Many intervention studies have investigated the effects of either dietary restriction [13-20] on metabolic and inflammatory outcomes. Improvements in systemic markers of low-grade inflammation often seem to increase with greater weight/fat loss [21]. There is strong scientific support for combining regular physical exercise with an energy restricted diet as the most effective treatment for obesity and in the management of type 2 diabetes [22].

Nicklas BJ [23] et al found that Average weight loss for the 95 women who completed the study was $12.1 \mathrm{~kg}(+/-4.5 \mathrm{~kg})$ and was not significantly different across groups. Maximal oxygen uptake increased more in the $\mathrm{CR}+$ vigorous-intensity group than in either of the other groups $(\mathrm{P}<0.05)$.

The CR-only group lost relatively more lean mass than did either exercise group $(\mathrm{P}<0.05)$. All groups showed similar decreases in abdominal visceral fat (approximately 25\%; $\mathrm{P}<0.001$ for all). However, changes in visceral fat were inversely related to increases in $\mathrm{O}(2) \max (\mathrm{P}<0.01)$. Changes in lipids, fasting glucose or insulin, and 2- $\mathrm{h}$ glucose and insulin areas during the oral-glucosetolerance test were similar across treatment groups. Davis CS et al [24] found that Average weight loss was approximately $0.2-0.8 \mathrm{~kg}$ per week. IER resulted in comparable weight loss to DER when overall energy restriction remained similar between diets. The majority of studies that reported body composition outcomes have shown equal efficacy for fat mass, fat-free mass and waist circumference, similar to our study.

Similarly Antoni R [25] found that The intermittent energy restriction (IER) approach to weight loss involves short periods of substantial (75-100 \%) energy restriction (ER) interspersed with normal eating. This study aimed to characterise the early metabolic response to these varying degrees of ER, which occurs acutely and prior to weight loss. Ten (three female) healthy, overweight/ obese participants (36 (SEM 5) years; 29.0 (sem 1.1) $\mathrm{kg} / \mathrm{m} 2$ ) took part in this acute three-way cross-over study. Participants completed three 1-d dietary interventions in a randomised order with a 1-week washout period: isoenergetic intake, partial $75 \%$ ER and total $100 \%$ ER. Fasting and postprandial (6-h) metabolic responses to a liquid test meal were assessed the following morning via serial blood sampling and indirect calorimetry. Food intake was also recorded for two subsequent days of ad libitum intake. Similarly Keogh JB et al [25] found that the effect of intermittent energy restriction (IER) compared to continuous energy restriction (CER) on weight loss after 8 weeks and weight loss maintenance after 12 months. Secondary aims were to determine changes in waist and hip measurements and diet quality. In a randomized 
parallel study, overweight and obese (body mass index $[\mathrm{BMI}] \geq 27 \mathrm{~kg} \mathrm{~m}(-2)$ ) women were stratified by age and BMI before randomization. Participants undertook an 8-week intensive period with weight, waist and hip circumference measured every 2 weeks, followed by 44 weeks of independent dieting. A food frequency questionnaire was completed at baseline and 12 months, from which diet quality was determined. Weight loss was not significantly different between the two groups at 8 weeks $(-3.2 \pm 2.1 \mathrm{~kg} \mathrm{CER,} \mathrm{n}=20,-2.0 \pm 1.9 \mathrm{~kg}$ IER, $\mathrm{n}=25 ; \mathrm{P}=0.06)$ or at 12 months $(-4.2 \pm 5.6$ $\mathrm{kg}$ CER, $\mathrm{n}=17-2.1 \pm 3.8 \mathrm{~kg}$ IER, $\mathrm{n}=19 ; \mathrm{P}=$ $0.19)$. Weight loss between 8 and 52 weeks was $0.7 \pm 49 \mathrm{~kg}$ CER vs. $-1 \pm 1.1 \mathrm{~kg}$ IER; $\mathrm{P}=0.6$ Waist and hip circumference decreased significantly with time $(\mathrm{P}<0.01)$, with no difference between groups.

Strong compensatory responses, with reduced resting metabolic rate (RMR), increased exercise efficiency (ExEff) and appetite, are activated when weight loss (WL) is achieved with continuous energy restriction (CER) which try to restore energy balance. Intermittent energy restriction (IER), where short spells of energy restriction are interspaced by periods of habitual energy intake, may offer some protection in minimizing those responses [26].

\section{Conclusion}

We thus conclude that even without caloric restriction a negative energy balance induced by increased caloric expenditure through exercise program causes improved fitness and favourable alterations in body composition and body fat.

Exercise enhances fat mobilization and catabolism accelerating body fat loss. Thus exercise of at least 60 minute possibly produces less accumulation of central adipose tissue. Exercise also reduces the risk of cardiovascular disease by reducing blood pressure in women living sedentary life style. However further study is needed in this aspect.

\section{Funding: Nil, Conflict of interest: None Permission of IRB: Yes}

\section{References}

1. Jeffrey S.flier, Eleftheria Maratos-Flier, biology of obesity. harrison's principles of internal medicine, 2012;18:622-5.
2. Owen CG, Whincup PH, Orfei L, Chou QA, Rudnicka AR, Wathern AK, Kaye SJ, Eriksson JG, Osmond C, Cook DG. Is body mass index before middle age related to coronary heart disease risk in later life? Evidence from observational studies. Int J Obes (Lond). 2009 Aug; 33(8):866-77.

3. Serdula MK, Ivery D, Coates RJ, Freedman DS, Williamson DF, Byers T. Do obese children become obese adults? A review of the literature. Prev Med. 1993 Mar;22(2):167-77.

4. Olshansky SJ, Passaro DJ, Hershow RC, Layden J, Carnes BA, Brody J, Hayflick L, Butler RN, Allison DB, Ludwig DS. A potential decline in life expectancy in the United States in the 21st century. N Engl J Med. 2005 Mar 17; 352(11): 1138-45.

5. World Health Organization. Interim Report of the Commission on Ending Childhood Obesity. Geneva, Switzerland: World Health Organization, 2015.

6. Obesity: preventing and managing the global epidemic. Report of a WHO consultation. World Health Organ Tech Rep Ser. 2000;894:i-xii, 1-253.

7. Belcher BR, Berrigan D, Papachristopoulou A, Brady SM, Bernstein SB, Brychta RJ, Hattenbach JD, Tigner IL Jr, Courville AB, Drinkard BE, Smith KP, Rosing DR, Wolters PL, Chen KY, Yanovski JA. Effects of Interrupting Children's Sedentary Behaviors With Activity on Metabolic Function: A Randomized Trial. J Clin Endocrinol Metab. 2015 Oct; 100(10):3735-43.

8. Feng J, Glass TA, Curriero FC, Stewart WF, Schwartz BS. The built environment and obesity: A systematic review of the epidemiologic evidence. Health \& Place. 2010;16(2):175-190.

9. Ding D, Sallis JF, Kerr J, Lee S, Rosenberg DE. Neighborhood environment and physical activity among youth a review. American journal of preventive medicine. 2011;41(4):442-455.

10. Ding D, Gebel K. Built environment, physical activity, and obesity: what have we learned from reviewing the literature? Health Place. 2012 Jan;18 (1):100-5. doi: 10.1016/j.healthplace. 2011. 08. 021. Epub 2011 Sep 13. 
11. Datar A, Nicosia N, Shier V. Parent perceptions of neighborhood safety and children's physical activity, sedentary behavior, and obesity: evidence from a national longitudinal study. American journal of epidemiology. 2013;177(10):1065-1073.

12. Prins RG, Kamphuis $\mathrm{CB}$, van Empelen $\mathrm{P}$, Beenackers MA, Brug J, Mackenbach JP, et al. Explaining socio-demographic differences in disengagement from sports in adolescence. European journal of public health. 2013;23(5): 811-816.

13. Fontana L., Villareal D. T., Weiss E. P., Racette S. B., Steger-May K., Klein S., et al. 2007. Calorie restriction or exercise: effects on coronary heart disease risk factors. A randomized, controlled trial. Am. J. Physiol. Endocrinol. Metab. 293: E197-E202.

14. Hammer S, Snel M, Lamb HJ, Jazet IM, van der Meer RW, Pijl H, Meinders EA, Romijn JA, de Roos A, Smit JW. Prolonged caloric restriction in obese patients with type 2 diabetes mellitus decreases myocardial triglyceride content and improves myocardial function. J Am Coll Cardiol. 2008 Sep 16;52(12):1006-12. doi: 10.1016/j.jacc. 2008.04.068

15. Larson-Meyer D. E., Heilbronn L. K., Redman L. M., Newcomer B. R., Frisard M. I., Anton S., et al. 2006. Effect of calorie restriction with or without exercise on insulin sensitivity, beta-cell function, fat cell size, and ectopic lipid in overweight subjects. Diabetes Care 29:1337-1344.

16. Wolever TM, Gibbs AL, Mehling C, Chiasson JL, Connelly PW, Josse RG, Leiter LA, Maheux P, Rabasa-Lhoret R, Rodger NW, Ryan EA. The Canadian Trial of Carbohydrates in Diabetes (CCD), a 1-y controlled trial of low-glycemicindex dietary carbohydrate in type 2 diabetes: no effect on glycated hemoglobin but reduction in Creactive protein. Am J Clin Nutr. 2008 Jan;87 (1): 114-25.

17. Balducci S, Zanuso S, Nicolucci A, Fernando F, Cavallo S, Cardelli P, Fallucca S, Alessi E, Letizia C, Jimenez A, Fallucca F, Pugliese G. Antiinflammatory effect of exercise training in subjects with type 2 diabetes and the metabolic syndrome is dependent on exercise modalities and independent of weight loss. Nutr Metab Cardiovasc Dis. 2010 Oct;20(8): 608-17. doi: 10.1016/j.numecd. 2009.04. 015. Epub 2009 Aug 19.

18. Imayama I, Ulrich CM, Alfano CM, Wang C, Xiao L, Wener MH, Campbell KL, Duggan C, Foster-Schubert KE, Kong A, Mason CE, Wang CY, Blackburn GL, Bain CE, Thompson HJ, McTiernan A. Effects of a caloric restriction weight loss diet and exercise on inflammatory biomarkers in overweight/obese postmenopausal women: a randomized controlled trial. Cancer Res. 2012 May 1;72(9):2314-26. doi: 10.1158/0008-5472.CAN-113092 .

19. Jorge ML, de Oliveira VN, Resende NM, Paraiso LF, Calixto A, Diniz AL, Resende ES, Ropelle ER, Carvalheira JB, Espindola FS, Jorge PT, Geloneze B. The effects of aerobic, resistance, and combined exercise on metabolic control, inflammatory markers, adipocytokines, and muscle insulin signaling in patients with type 2 diabetes mellitus. Metabolism. 2011 Sep;60(9):1244-52. doi: 10.1016/j.metabol.2011.01.006. Epub 2011 Mar 4.

20. Thompson D., Markovitch D., Betts J. A., Mazzatti D., Turner J., and Tyrrell R. M.. 2010. Time course of changes in inflammatory markers during a 6-mo exercise intervention in sedentary middle-aged men: a randomized-controlled trial. J. Appl. Physiol. 108:769-779.

21. Selvin E, Paynter NP, Erlinger TP. The effect of weight loss on C-reactive protein: a systematic review. Arch Intern Med. 2007 Jan 8;167(1):31-9.

22. Nathan DM, Buse JB, Davidson MB, Ferrannini E, Holman RR, Sherwin R, Zinman B; American Diabetes Association; European Association for Study of Diabetes. Medical management of hyperglycemia in type 2 diabetes: a consensus algorithm for the initiation and adjustment of therapy: a consensus statement of the American Diabetes Association and the European Association for the Study of Diabetes. Diabetes Care. 2009 Jan;32(1):193-203. doi: 10.2337/dc089025. Epub 2008 Oct 22.

23. Nicklas BJ, Wang $\mathrm{X}$, You $\mathrm{T}$, Lyles MF, Demons J, Easter L, Berry MJ, Lenchik L, Carr JJ. Effect of exercise intensity on abdominal fat loss 


\section{Original Research Article}

during calorie restriction in overweight and obese postmenopausal women: a randomized, controlled trial. Am J Clin Nutr. 2009 Apr;89(4):1043-52. doi: 10.3945/ajcn.2008.26938. Epub 2009 Feb 11.

24. Davis CS, Clarke RE, Coulter SN, Rounsefell KN, Walker RE, Rauch CE, Huggins CE, Ryan L. Intermittent energy restriction and weight loss: a systematic review. Eur J Clin Nutr. 2016 Mar;70 (3):292-9. doi: 10.1038/ejcn.2015.195. Epub 2015 Nov 25.
25. Antoni R1, Johnston KL Investigation into the acute effects of total and partial energy restriction on postprandial metabolism among overweight/ obese participants. Br J Nutr. 2016 Mar 28;115 (6): 951-9.

26. Coutinho SR1, Halset EH Compensatory mechanisms activated with intermittent energy restriction: A randomized control trial. Clin Nutr. 2017 Apr 7. pii: S0261-5614(17)30125-5. doi: 10. 1016 /j. clnu.2017.04.002.

\section{How to cite this article?}

Vandana B Dudhamal, Sayeda Afroj. Effect of short term exercise on abdominal obesity and blood pressure. Int J Med Res Rev 2017;5(08):796-801.doi:10.17511/ijmrr. 2017.i08.04. 